\title{
Hemoglobin level and prevalence of anemia in Soliga tribal children of Karnataka, India
}

\author{
S C Jai Prabhakar', M R Gangadhar ${ }^{2}$
}

${ }^{1}$ Assistant Professor, Centre for Multi-disciplinary Development Research (CMDR), Dharwad, Karnataka, India. ${ }^{2}$ Professor, Department of Anthropology, University of Mysore, Mysore, Karnataka, India.

\begin{abstract}
Hemoglobin status of tribal children in Karnataka has not been investigated adequately and extensively. Hematological parameters help to understand the normal growth and nutritional status of the children. A crosssectional purposive sampling study was undertaken to determine the prevalence of anemia among 152 Soliga tribal children belonging to $6+$ to $10+$ years of Mysore district, Karnataka, India. Hemoglobin level was determined by cyanmethaemoglobin method. As per the WHO cut-off points, the children were grouped under mild, moderate and severe anemia where the level of hemoglobin below $11.5 \mathrm{~g} / \mathrm{dL}$. BMI values were estimated based on the measurements of height and weight of the children. The overall prevalence of anemia was $91.4 \% ; 7.2 \%$ mild, $74.3 \%$ moderate, and 9.9\% severe anemia. Mean hemoglobin values between boys and girls of 7+ years age group were statistically significant. A higher proportion of girls were severely anemic in the age group of $9+$ and $10+$ years than boys. The prevalence of different grades of anemia was more or less equally distributed among boys and girls of Soliga children. Remarkably, about $94.3 \%$ normal BMI children were anemic. Comparison of mean values of anemia and BMI between boys and girls were found statistically significant. The level of hemoglobin among Soliga Children in Karnataka is a cause for concern. Appropriate measures should be taken by the respective authorities to decrease the prevalence of anemia and improve the condition of health among the children.
\end{abstract}

Keywords: Hemoglobin, Anemia, Sologa tribe, Children, India.

\section{Introduction}

Worldwide, at any given moment, more individuals have iron-deficiency anemia than any other health problem. ${ }^{1}$ Anemia is a nutritional problem and its prevalence is higher in developing countries than developed countries. ${ }^{2}$ In developing countries most highly affected population groups are pregnant, non-pregnant women, pre-school and school age children.

On the whole about 3.8 billion (43\% anemia in children) people in the world have Iron deficiency anemia. ${ }^{3-5}$ The prevalence of anemia is an important health indicator. ${ }^{6}$ It is estimated that $53 \%$ of school children in developing countries are suffering from iron deficiency anemia. ${ }^{5}$ Like many parts of the world, nutritional anemia is one of the important public health problems in India and large segment of the population approximately 50\% suffer from different grades of anemia. Among all, children are considered to be the most valuable assets of any nation, ${ }^{8}$ though they constitute a vulnerable group and easy susceptibility to infections and diseases.

Anemia is a condition in which the number of red blood cells (and consequently their oxygen carrying capacity) is insufficient to meet the body's physiologic needs. It is associated with impaired growth, delay in development, behavioral abnormalities and impair cognitive functions in infants and children., ${ }^{9}$ An increased likelihood of mild or moderate retardation is associated with anemia, independent of birth, weight, maternal education, gender, race-ethnicity, the mother's age or the child's age. Moreover, several studies ${ }^{11-17}$ report that prevalence of anemia is higher among the underprivileged communities. In general, tribal populations are considered to be under-

\section{Practice Points}

- Anemia is a nutritional problem and its prevalence is higher in developing countries than developed countries and worst sufferers are pre-school and school age children along with pregnant and non-pregnant women.

- Hemoglobin status of tribal children in Karnataka has not been investigated adequately and extensively.

- Anemia was determined by cyanmethaemoglobin method and children were grouped under the classification of WHO cutoff values.

- The overall prevalence of anemia among these tribal children was $91.4 \%$ and more or less evenly distributed among boys and girls. Remarkably, about $94.3 \%$ normal BMI children were anemic.

- Appropriate steps should be adopted by the respective authorities to lessen the prevalence of anemia among these tribal groups and improve the status of childhood health.

privileged in India $^{18}$ and very few studies were conducted on these populations specifically on school aged children.

Tribal population is about 6.5 percent of the total population of Karnataka State, India. According to the latest census ${ }^{19}$ report, the total population of Soliga is 33,819 , which is $0.7 \%$ of the total tribal population of

Correspondence: Dr. S. C. Jai Prabhakar, Assistant Professor, Centre for Multi-disciplinary Development Research (CMDR), Dr. BR Ambedkar Nagar, near Y. Shettar Colony, Dharwad-580004, Karntaka, India. Email: anthroprabhakar@gmail.com.

South East Asia Journal of Public Health 2016;6(2):37-41. (C) 2016 Prabhakar \& Gangadhar, publisher and licensee Public Health Foundation Bangladesh. This is an Open Access article which permits unrestricted non-commercial use, provided the original work is properly cited. 
the state and $10.1 \%$ to total tribal population of Mysore District. Soligas are mainly distributed in the hilly parts of Mysore, Chamarajanagar, and Mandya districts in Karnataka. They are aboriginal inhabitants distributed in southern provinces of Karnataka and Tamil Nadu. They are endogamous in nature, but clan exogamy is the norm. Cross cousin marriages are preferred and adult marriage is in practice. They are non-vegetarian in eating habit and Ragi is their staple food. Physically Soligas were below medium statured with long and narrow head shape, oval face and broad nose. ${ }^{20}$ However, there are a scarce data on prevailing occurrence of anemia in Soliga children of Mysore. A normal hemoglobin level should be defined for each particular group of the population in order to see the prevalence of anemia. In view of this, the present study was undertaken to estimate the prevalence of anemia among Soliga children aged 6-10 years from the different settlements of Mysore district, Karnataka, India. An attempt was also made to assess its association with different variables such as age, gender and Body Mass Index (BMI).

\section{Materials and methods}

The cross-sectional study was conducted to 152 Soliga tribal children aged $6+$ to $10+$ years through purposive sampling method. The samples were collected from different tribal settlements of Hunsur, Piriyapattana and HD Kote taluks of Mysore District, Karntaka State, India. The related tribal settlements were 12 to $55 \mathrm{~km}$ from the taluk headquarters. Prior to the survey, institutional ethical committee clearance was obtained. Parents' of the wards were contacted through key informants, school teacher and headman of the settlement. The purpose of the study was explained prior to obtain their consent. Upon the receipt of their informed consent, children were included in the study. Further oral consent was obtained from each of the school children. The children between the ages of 6.006.99 were included into $6+$ age group, 7.00-7.99 into $7+$ age group and so on up to $10+$ age group. ${ }^{15}$

\section{Experimental procedure}

Estimation of hemoglobin ( $\mathrm{Hb})$ was done using cyanmethemoglobin method. ${ }^{21}$ Blood sample was drawn by finger prick method. A fixed quantity $(20 \mu \mathrm{L})$ of anticoagulated blood was diluted with a $5 \mathrm{ml}$ of standardized Drabkin's solution. The solution in the test tube was inverted and mixed thoroughly and allowed to stand for 10 minutes. The solution was read in photoelectric calorimeter at $540 \mathrm{~nm}$ and values were compared with a standard table. All observations were made by a single person to prevent inter-observer bias. Different grades of anemia were diagnosed when $\mathrm{Hb}$ concentration was less than $11.5 \mathrm{~g} / \mathrm{dL}$ for children. According to World Health Organisation (WHO) ${ }^{22}$ standards, if the hemoglobin concentration above $10 \mathrm{~g} /$ $\mathrm{dL}$ but below $11.5 \mathrm{~g} / \mathrm{dL}$ is mild anemia, when the concentration between 7 and $10 \mathrm{~g} / \mathrm{dL}$ is moderate anemia and when it below $7 \mathrm{~g} / \mathrm{dL}$ is severe anemia. ${ }^{3}$ Interview schedule were used to collect the details of the health condition. Height and weight of each child was measured to compute the BMI value.

\section{Statistical analysis}

Collected data were computed for statistical analysis by SPSS software version 13.0. Results of the study are presented in mean, standard deviation and probability value. Independent t-test was used to compare the means of anemic and non-anemic children. ANOVA, Chi-square test were also applied to find the statistical significance in different groups of children. Cross tabs were used to present the comparison between BMI and $\mathrm{Hb}$ values. The level of significance was set at $p<0.05$.

\section{Results}

Of the 152 children, $91.4 \%$ were found to be anemic and affected with various grades of anemia between 6 to 10 years age group. Table 1 shows, the prevalence of anemia was more among girls $(92 \%)$ compared to the boys $(90.9 \%)$. Although a higher number of boys were anemic at the age group of $7+$ to $9+$ years. The gap of hemoglobin values between the genders at the age of 7 and $10+$ years has widened (Figure 1).

It is apparent from the Table 2 that mean hemoglobin values compared between boys and girls aged 7 years were significant $(p<0.05)$. But the mean values of the

Table 1: Prevalence of anemia in Soliga children based on blood hemoglobin concentration $(\mathrm{g} / \mathrm{dL})$

\begin{tabular}{|l|c|c|c|}
\hline Gender & Number & Normal (\%) & Anemic (\%) \\
\hline Boys & 77 & $9.1 \%$ & $90.9 \%$ \\
\hline Girls & 75 & $8 \%$ & $92 \%$ \\
\hline Overall & 152 & $8.6 \%$ & $91.4 \%$ \\
\hline
\end{tabular}

Figure 1: Prevalence of anemia in relation to age and gender

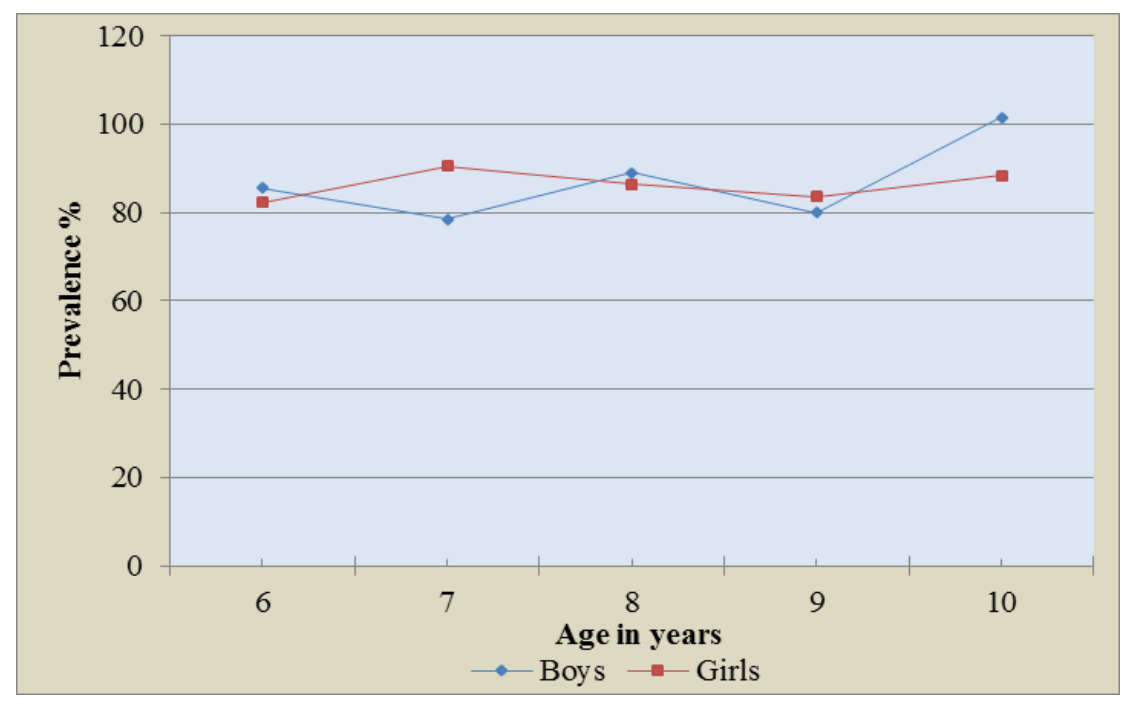

South East Asia Journal of Public Health 2016;6(2):37-41 
Prabhakar \& Gangadhar - Prevalence of anemia in Soliga tribal children

Table 2: Correlation of age and gender with mean hemoglobin $(\mathrm{g} / \mathrm{dL})$ in Soliga children

\begin{tabular}{|c|c|c|c|c|}
\hline Age (yrs) & Gender & Total number & $\begin{array}{c}\text { Hemoglobin }(\mathrm{g} / \mathrm{dL}) \\
\text { mean } \pm \text { SD }\end{array}$ & $p$-value \\
\hline \multirow[t]{2}{*}{6 years } & Boys & 14 & $8.56 \pm 2.35$ & \multirow{2}{*}{0.614} \\
\hline & Girls & 15 & $8.22 \pm 1.08$ & \\
\hline \multirow[t]{2}{*}{7 years } & Boys & 14 & $7.85 \pm 1.05$ & \multirow{2}{*}{$0.029 *$} \\
\hline & Girls & 17 & $9.05 \pm 1.69$ & \\
\hline \multirow[t]{2}{*}{8 years } & Boys & 13 & $8.90 \pm 1.35$ & \multirow{2}{*}{0.617} \\
\hline & Girls & 15 & $8.63 \pm 1.53$ & \\
\hline \multirow[t]{2}{*}{9 years } & Boys & 24 & $8.00 \pm 1.10$ & \multirow{2}{*}{0.333} \\
\hline & Girls & 15 & $8.36 \pm 1.11$ & \\
\hline \multirow[t]{2}{*}{10 years } & Boys & 12 & $10.15 \pm 2.11$ & \multirow{2}{*}{0.150} \\
\hline & Girls & 13 & $8.83 \pm 2.34$ & \\
\hline
\end{tabular}

*Statistically significant $(\mathrm{p} \leq 0.05)$

age $6+, 8+, 9+$ and $10+$ were not statistically significant. The mean hemoglobin values of girls between the age 6 - 7 and boys of 9-10 years were linearly increasing; however it was not sequential in other age groups among both the sexes.

If the age and sex were combined, the different grades of anemia among the sampled children (Table 3) describe that $7.2 \%$ were mildly anemic, $74.3 \%$ were moderately and $9.9 \%$ were severely anemic. There were no non-anemic children reported among 9+ year aged children. Out of total anemic children, a higher proportion of girls were severely anemic in the age group of $9+(13.3 \%)$ and $10+$ years $(15.4 \%)$ than boys of $6+$ and $7+$ years but only none of the severely anemic children diagnosed at 8 years age group. The highest moderately graded anemia was $86.7 \%$ among girls in the age group of $8+$ and $83.3 \%$ among $9+$ year aged boys. Mildly anemic boys $(23.3 \%)$ were more in their percentage than girls. However, the mild, moderate and severe grades of anemia between boys and girls were not statistically significant in all the age groups.

As seen from the Table 4, the result of BMI values compared with National Centre for Health Statistics reference standards (NCHS) ${ }^{23}$ showed $48.7 \%$ children were low in their weight and $5.3 \%$ children were very low weight but found no over weighed children. The relationship between hemoglobin level and BMI of children showed that $87.8 \%$ low weight children and cent per cent very low weight children were anemic. The mean values of anemia and BMI compared between boys and girls revealed statistical significance $(p<0.05)$.

\section{Discussion}

An estimated global prevalence of anemia among school-age children is $37 \%{ }^{3}$ However, the prevalence of anemia (91.4\%) indicated in the present study was higher than the national prevalence. ${ }^{24}$ The results of the present study corroborated the study among tribal school children of Rajastan $(93.7 \%)^{16}$ and $93 \%$ anemia in Varanasi school children. ${ }^{25}$ But it was higher in the preset study than in Oraon, Santhal and Munda tribal children of Bihar $(78.1 \%){ }^{26}$ Kattankulathur school children in Tamil Nadu $(52.8 \%)^{27}$ and urban school children of Punjab $(51.5 \%){ }^{28}$ In contrast, the prevalence of anemia was lower in the present study than hill Korava tribal children of Madhya Pradesh (98.9\%). ${ }^{13}$

The present study results on prevalence of different grades of anemia with differential in age and gender revealed that majority of children were moderately anemic $(74.3 \%)$ than mild and severe grade. Similar findings of earlier study confirmed that $60.2 \%$ of Rajastan tribal children were moderately anemic, $32.9 \%$ severe and $0.06 \%$ mildly anemic. ${ }^{16}$ However, a

Table 3: Age and gender specific prevalence of anemia in Soliga children

\begin{tabular}{|c|c|c|c|c|c|c|c|}
\hline Age (yrs) & Gender & $\begin{array}{c}\text { Non-Anemic } \\
\text { (11.5 or } \\
\text { more) }\end{array}$ & $\begin{array}{c}\text { Mild } \\
\text { Anemia } \\
(10-11.49)\end{array}$ & $\begin{array}{c}\text { Moderate } \\
\text { Anemia } \\
(7-9.99)\end{array}$ & $\begin{array}{c}\text { Severe } \\
\text { Anemia } \\
(<7)\end{array}$ & $\begin{array}{c}\text { Total } \\
\text { Anemia } \\
(<11.5)\end{array}$ & $p$-value \\
\hline \multirow[t]{2}{*}{6 years } & Boys & $2(14.3 \%)$ & $0(0.0 \%)$ & $9(64.3 \%)$ & $3(21.4 \%)$ & $12(85.7 \%)$ & \multirow[t]{2}{*}{0.375} \\
\hline & Girls & $0(0.0 \%)$ & $2(13.3 \%)$ & $11(73.3 \%)$ & $2(13.3 \%)$ & $15(100 \%)$ & \\
\hline \multirow[t]{2}{*}{7 years } & Boys & $0(0.0 \%)$ & $0(0.0 \%)$ & $11(78.6 \%)$ & $3(21.4 \%)$ & $14(100 \%)$ & \multirow[t]{2}{*}{0.163} \\
\hline & Girls & $2(11.8 \%)$ & $1(5.9 \%)$ & $13(76.5 \%)$ & $1(5.9 \%)$ & $15(88.2 \%)$ & \\
\hline \multirow[t]{2}{*}{8 years } & Boys & $0(0.0 \%)$ & $3(23.1 \%)$ & $10(76.9 \%)$ & $0(0.0 \%)$ & $13(100 \%)$ & \multirow[t]{2}{*}{0.070} \\
\hline & Girls & $2(13.3 \%)$ & $0(0.0 \%)$ & $13(86.7 \%)$ & $0(0.0 \%)$ & $13(86.7 \%)$ & \\
\hline \multirow[t]{2}{*}{9 years } & Boys & $0(0.0 \%)$ & $2(8.3 \%)$ & $20(83.3 \%)$ & $2(8.3 \%)$ & $24(100 \%)$ & \multirow[t]{2}{*}{1.000} \\
\hline & Girls & $0(0.0 \%)$ & $2(13.3 \%)$ & $11(73.3 \%)$ & $2(13.3 \%)$ & $15(100 \%)$ & \\
\hline \multirow[t]{2}{*}{10 years } & Boys & $5(41.7 \%)$ & $1(8.3 \%)$ & $6(50.0 \%)$ & $0(0.0 \%)$ & $7(58.3 \%)$ & \multirow[t]{2}{*}{0.108} \\
\hline & Girls & $2(15.4 \%)$ & $0(0.0 \%)$ & $9(69.2 \%)$ & $2(15.4 \%)$ & $11(84.6 \%)$ & \\
\hline
\end{tabular}

Table 4: Relation between anemia and BMI in Soliga chidlren

\begin{tabular}{|l|c|c|c|c|c|}
\hline Anemia & Very Low Weight & Low Weight & Normal Weight & Over Weight & $\boldsymbol{p}$ - value \\
\hline Non-Anemic & $0(0.0 \%)$ & $9(12.2 \%)$ & $4(5.7 \%)$ & $0(0.0 \%)$ & 0.308 \\
\hline Anemic & $8(100 \%)$ & $65(87.8 \%)$ & $66(94.3 \%)$ & $0(0.0 \%)$ & $0.012^{*}$ \\
\hline BMI Total & $8(5.3 \%)$ & $74(48.7 \%)$ & $70(46 \%)$ & $0(0.0 \%)$ & $0.009^{*}$ \\
\hline
\end{tabular}

*Statistically significant $(\mathrm{p} \leq 0.05)$ 
lower prevalence of mild $(26.29 \%)$, moderate $(36.57 \%)$ and severe $(14.86 \%)$ anemia among Jenu Kuruba tribal children were reported in a study. ${ }^{17}$ Another study reported by Sidhu ${ }^{1]}$ that $95.65 \%$ of Scheduled Caste children of Amrutsar were having different grades of anemia. In their study, Sharma et $a{ }^{29}{ }^{29}$ concluded that most of the Gaddi girls of Chamba and Kangra district of Himachal Pradesh were suffering from serious cases of anemia and no single female children had normal hemoglobin level. Study on school going girls of Karnataka reported that $31.1 \%$ were moderately anemic, $23 \%$ were mildly anemic and $6.6 \%$ were severely anemic. $^{30}$ Basu et al. ${ }^{31}$ studied the school going adolescents of Chandigarh and reported that, the prevalence of anemia was $23.9 \%$ and $7 \%$ of teenage girls and boys respectively.

The present study shows the boys and girls of Soliga tribe can equally grouped into the same state of hemoglobin concentration, but no single boy found to be a nonanemic in the age group of $7+, 8+$ and $9+$ years. Prevalence of anemia in our study was higher in low weight children when compared to normal BMI children. The striking finding was that $94.3 \%$ of children of normal BMI had anemia. It is evident from the results that a significant proportion of apparently healthy children were also anemic. However the present study was not specifically designed to study all risk factors for anemia, we stipulate that Soliga children were consuming mainly cereal-based diet and had less awareness of nutritional diet which lead to anaemia.

\section{Conclusion}

Majority of the children under the study were anemic and low in their BMI values because of many factors like less availability of iron rich food and nutritional diet. However, there are certain limitations in the present study, including the size of the sample, socioeconomic status in detail, lack of data on dietary intake etc. It can be concluded that the prevalence rate of anemia is high in the sample population and require to improve the nutritional status of the children. The study recommended that the marginalized scheduled tribe community should be made to consume a rich source of Vitamin A, C and folic acid like green leafy vegetables, fruits, tubers, jaggery and so forth along with food of animal origin. Tribal children should be screened periodically and a daily dosage of $30-60 \mathrm{mg} /$ day of elemental iron, depending on the child's age and weight should be provided. ${ }^{22}$ Appropritate child welfare schemes need to be launched and medical infrastructure should be strengthened in the tribal habitats. From the point of national public health view, it is necessary to improve the nutritional status of the tribal population specifically children at large.

\section{Competing interest}

The authors declared no potential conflicts of interest with respect to the research, authorship, and/or publication of this article.

\section{References}

1. WHO. Global burden of diseases: 2004 update. Geneva: World Health Oorganization, 2008.

2. Djokic D, Drakulovic MB, Radojicic Z, Crncevic Radovic L, Rakic L, Kocic S, et al. Risk factors associated with anemia among Serbian school-age children 7-14 years old: results of the first national health survey. Hippokratia 2010;14:252-60.

3. WHO. Preventing and controlling iron deficiency anaemia through primary health care. A guide for health administrators and programme managers. Geneva: World Health Organization, 1989.

4. WHO. Life in the 21st century: a vision for all. Report of the Director General. Geneva: World Health Organization, 1998.

5. CC/SCN. The World Nutritional Situation: Nutrition during the life cycle- $4^{\text {th }}$ Report. The UN System's Forum for Nutrition. Geneva:Administrative Committee on Coordination/Sub-Committee on Nutrition, 2000.

6. World Health Organization. Haemoglobin concentrations for the diagnosis of anaemia and assessment of severity. Vitamin and Mineral Nutrition Information System. Geneva, World Health Organization, 2011.

7. NIN. Anaemia in endurance capacity (Physical performance). Annual report. Hyderabad: National Institute of Nutrition (ICMR), 1986.

8. Das NK, Das R. A study on cause of death among the tribal children of Udalguri district, Assam. Int J Med Sci Public Health 2015; 4:1060-65.

9. ICMR. Studies on preschool children. Technical Report Series No. 26. New Delhi: Indian Council of Medical Research, 1977.

10. Hioui ME, Farsi M, Aboussaleh Y, Ahami AOT, Achicha A. Prevalence of malnutrition and anemia among preschool children in Kenitra, Morocco. Nutr Ther Metab 2010;28:73-6.

11. Vasanthi G, Pawashe AB, Susie H, Sujatha $\mathrm{T}$, Raman L. Iron nutritional status of adolescent girls from rural area and urban slum. Indian Pediatr 1994; 31:127-32.

12. Sidhu S. Prevalence of anaemia in Scheduled Caste children of Mahl village in Amritsar district of Punjab. J Hum Ecol 1997; 8:495-97.

13. Sharma KKN. Assessment of haemoglobin level among the Hill Korwa primitive tribal children of Madhya Pradesh, India. J Hum Ecol 1998; 9:525-26.

14. Sidhu S, Kumari K, Uppal M. Prevalence of anemia in Schedule Caste preschool children of Punjab. Indian. J Med Sci 2002; 56:218221.

15. Sidhu S, Kumari K, Uppal M. Prevalence of anaemia in Bazigar (Ex-nomadic Tribe) preschool children of Punjab. J Hum Ecol 2007; 21:265-267.

16. Vyas S, Choudhry M. Prevalence of anaemia in tribal school children. J Hum Ecol 2005; 17:289-291. 
17. Prabhakar Jai SC, Gangadhar MR. Prevalence of amemia in Jenukuruba primitive tribal children of Mysore district, Karnataka. Anthropologist 2009; 11:49-51

18. Bisai S, Bose $\mathrm{K}$, Dikshit S. Under nutrition among slum children aged 3-6 years in Midnapore town, India. Internet J Bio Anthropol 2009;2:2

19. Census of India 2011. Population Enumeration Data (Final Population). http:// www.censusindia.gov.in/2011census/ population_enumeration.html (accessed Dec 2016)

20. Karve I. Anthropometric measurements in Karnataka, Orissa and a comparison of these two regions with Maharashtra. J Anthropological Soc 1954; 8:47-75.

21. Gopaldas T, Seshadri S. Method for determination of blood hemoglobin. In T Gopaldas, $\mathrm{S}$ Seshadari (Eds.) Nutrition: Monitoring and Assessment. Delhi: Oxford University Press, 1987:205.

22. World Health Organization. Iron Deficiency Anaemia: Assessment, Prevention, and Control, A guide for programme managers. Geneva: World health Organiztion, 2001.

23. WHO. Physical Status: The use and interpretation of anthropometry. Technical Report Series No. 854. Geneva: World Health Organization, 1995.
24. IIPS. National Family Health Survey (NFHS-3) 2005-06: India. Mumbai: International Institute for Population Sciences (IIPS) and Macro International, 2007.

25. Agarwal DK, Upadhyay SK, Agarwal KN, Singh $\mathrm{RD}$, Tripathi AM. Anaemia and mental functions in rural primary school children. Ann Trop Paediatr 1989; 9:194-8.

26. Rao TVRK, Vijay T. Malnutrition and anemia in tribal pediatric population of Purnia district (Bihar). Indian Pediatrics 2006; 43:181-2.

27. Sudhagandhi B, Sundaresan S, William WE, Prema A. Prevalence of anemia in the school children of Kattankulathur, Tamil Nadu, India. Int J Nutr Pharmacol Neurol Dis 2011; 1:184-8.

28. Verma M, Chhatwal J, Kaur G. Prevalence of anemia among urban school children of Punjab. Indian Pediatr 1998; 35:1181-6.

29. Sharma Shubhangna, Rani R and Samkaria M. Prevalence of anemia and malnutrition among Gaddi girls of Chamba and Kangra ditrict of Himachal Pradesh. Stud Tribes Tribals 2007; 5:139-42.

30. Vinod Kumar CS, Anand Kumar H, Sunitha V, Indu Kapur. Prevalence of anemia and worm infestation in school going girls at Gulbarga, Karnataka, Indian Pediatr 2003; 40:70-2.

31. Basu S, Basu S, Hazarika R, Parmar V. Prevalence of anemia among school going adolescents of Chandigarh. Indian Pediatr 2005;42:593-7. 